\title{
Physicochemical and sensory properties of blends from beniseed, trifoliate yam and wheat flours
}

\author{
Ngozi U. Arisa1, Aminat Adelekan', Oluwatosin O. Malomo', Olayemi Eyituoyo Dudu ${ }^{\text {* }}$ \\ ${ }^{1}$ Department of Chemistry, Food and Nutritional Sciences, College of Natural and Applied Sciences, Bells University of \\ Technology, Ota, Ogun State. \\ Coressponding Author's Email: duduolayemi@live.com
}

\begin{abstract}
Composite flour blends of; wheat flour, beniseed flour and trifoliate yam of ratios; 90:5:5(WBT1), 70:15:15 (WBT2) and 50:25:25 (WBT3) respectively were utilized in the production of biscuits; WBTB1, WBTB2, WBTB3 respectively. Increase in beniseed and trifoliate yam substitution ensued improvements in; protein $(0.78 \%$ and $3.49 \%$, respectively), fat $(5.47 \%$ and $2.79 \%$, respectively), ash ( $0.89 \%$ and $0.80 \%$ respectively), and crude fibre $(2.27 \%$ and $1.30 \%$ respectively) and decline $(P<0.05)$ in; moisture $(2.29 \%$ and $1.67 \%$., respectively) and carbohydrate $(7.08 \%$ and $6.24 \%$, respectively) of both composite flours and biscuits. Magnesium $(0.27 \%)$, manganese $(0.07 \%)$, sodium $(0.14 \%)$, Calcium $(0.38 \%)$, Iron $(0.09 \%)$ and copper $(0.15 \%)$ contents of the composite flours were boosted with increase in beniseed and trifoliate yam. WBT1 had the superior; bulk density, water absorption capacity and swelling capacity $(0.66 \mathrm{~g} / \mathrm{ml}, 149.92 \%$ and $6.85 \mathrm{ml}$., respectively). WBTB1 was the most sensory accepted. This study further indicates the suitability of cereal-tuber based flours for the baking industry.
\end{abstract}

Keywords: Wheat, Beniseed, Trifoliate yam, Composite flour, Biscuit

\section{INTRODUCTION}

Beniseed also known as "Sesame" (Sesame indicum) is an oil seed predominantly grown in northern and central Nigeria (Abou-Garbia et al. 2000). It is valued throughout history for its contribution as a food additive, in human nutrition (rich in edible oil (44-58\%), protein (18 -25\%), carbohydrate (13.5\%) and ash (5\%)) and its therapeutic prowess in disease prevention and promoting well-being (Morris, 2002; Uaboi-Egbenni et al. 2008; USDA, 2009). Beniseeds are highly valued for their oil which is remarkably resistant to rancidity (Weiss, 2000). The oil has a natural antioxidant which prevents aging and vital for the production of liver cells (Njoku et al. 2009). It contains better quality protein than most legumes and highly rich in; vitamin $\mathrm{E}$, calcium, potassium, phosphorus, vitamin B, iron and contains no cholesterol (Dawodu, 2009; Adeniyan et al. 2013).

Also, its protein has a desirable amino acid profile and good nutritional value similar to soybean and better off compared to most legumes (Mohammed and Hamza 2008). Most especially it contains a considerably high methionine content which is limiting in most legumes (Osidipe, 2012). However, raw beniseeds contain oxalate and phytate which are substances that prevent the accessibility of minerals (anti-nutritional factors) in the human system (Akanji, 2003).

Yam is a tuber that belongs to the genus Dioscorea. Of the estimated $300-600$ species available, there are just over half-dozen species grown for consumption while others are grown for medicinal purposes. West Africa is the principal producer of yam on a global scale with the most common grown species namely; white yam (Dioscorea rotundata), water yam (Dioscorea alata), Chinese yam (Dioscorea esculenta) and trifoliate yam (Dioscorea domentorum) (FAO, 2003). Yams are valued for their high carbohydrate content alongside its root and tuber counterparts (cassava, potato, sweetpotato and taro). Trifoliate yam is a species upon which limited work has been done in terms of production and utilization though it is high yielding compared to other yams. It is not widely used because of the inferior quality of the tubers, bitter taste and poor binding capacity of its flours (Martin and Degras 1978; Ogbuagu, 2008). The tubers occur in clusters and have yellow edible flesh. The tubers are highly bitter especially the wild ones, however, some 
cultivars have only slight bitter taste and cook faster than others (Sefa-Dedeh and Afoakwa 2001). It grows readily on various soils, the yield being 3-7 times that of other widely grown yam species (Treche and Guion 1979). The Trifoliate yam has been neglected in attempts to process roots and tubers into more durable and value added form. This is because of the severe hardening that develops post-harvest due to bruising and makes the tuber difficult to cook. Processing the tubers into a shelf stable product offers an alternative to fresh storage (Abiodun and Akinoso 2015).

The looming economic need by African countries in harnessing the high carbohydrate qualities of their indigenous root and tuber crops has facilitated their use in conjunction with wheat in several composite flours which have been utilized in an array of food products (Himeda et al. 2014; Chandra et al. 2015). Replete studies have investigated the utilization of both Trifoliate yam and beniseed flours as part of composite flour blends with cassava and wheat flour or both in the production of snacks, confectionaries, pastries and bread which provided remarkable outcomes (Abiodun et al. 2010; Ezeocha et al. 2011; Eke-Ejiofo and Owuno, 2012; Emmanuel-Ikpeme et al. 2012). However, there has not been any reported investigation of the utilisation of composite flour mix of wheat, beniseed and trifoliate yam. Therefore, this paper presents hereby another composite flour from underutilized flours which is aimed at providing an improved viable option for Wheat flour due to its overreliance by the baking industry.

\section{MATERIALS AND METHODS}

\section{MATERIALS}

Fresh trifoliate yam and beniseeds were obtained from Oyingbo market in Lagos state Nigeria.Whole wheat flour (Honeywell), whole milk powder (Peak), fat (Topper) and granulated sugar (Dangote) were sourced from a credible retail store (Justrite stores, Lagos). All reagents used were all of analytical grade and were sourced from accredited suppliers. Other materials used in this study were derived from credible sources.

\section{Production of Beniseed flour}

The beniseeds after purchase were sorted to remove contaminants, weighed and steeped in water at $25^{\circ} \mathrm{C}$ for 17-18 $\mathrm{h}$ to ease the dehulling process. The seeds were dehulled by sedimentation washing, dried at $40^{\circ} \mathrm{C}$ using a convection oven for $24 \mathrm{~h}$ and then roasted at $110^{\circ} \mathrm{C}$ for $30 \mathrm{~min}$. The roasted beniseeds were milled using an attrition mill, then passed through a 100-mesh sieve and packaged in air tight containers.

\section{Production of trifoliate yam flour}

The tubers were; washed, peeled, sliced $(0.5 \mathrm{~cm}$ slices), boiled for 30minutes and dried in convection oven at $60^{\circ} \mathrm{C}$ for $48 \mathrm{~h}$. The dried samples were milled using a hammer mill and sieved through a 100-mesh sieve.

\section{Blend formulation}

Three composite flour blends were formulated based on percentage proportions of wheat flour, beniseed flour and trifoliate yam flour in the ratio; 5:5:90 (WBT1), 15:15:70 (WBT2) and 25:25:50 (WBT3) respectively using a machine food mixer (Kenwood M907 D England). Whole wheat flour (WWF) was used as control.

\section{Biscuit formulation and production}

The biscuit formulation is presented in Table 1. Sugar and fat were mixed until fluffy in a horizontal spindle mixer. Egg and whole milk were added and mixing was continued for 40 minutes. Composite flour, baking powder, vanilla flavour and salt were slowly introduced into the mixture and mixed until dough formation. The dough obtained were kneaded to a uniform thickness of $0.4 \mathrm{~cm}$. Biscuit doughs were cut $(4 \mathrm{~cm})$, embossed, baked (at $160^{\circ} \mathrm{C}$ for 15 minutes), cooled and stored for analysis.

\section{Chemical composition}

The moisture content of the samples was determined using the procedure described by AOAC (2004). The protein (Kjeldahl), fat (Soxhlet), crude fibre and ash were determined by the methods described by AOAC (1990) methods. Carbohydrate was determined by difference $(100$ - Moisture + Ash + Crude protein + Fat contents).Magnesium, Calcium, Sodium, Manganese, Iron, Zinc, and Copper were determined by methods described by AOAC (1990). Phosphorous was determined by method described by Ceirwyn (1998).

The ash obtained from each sample was digested with $5 \mathrm{ml}$ of $2 \mathrm{M}$ hydrochloric acid and heated to dryness on a heating mantle. $2 \mathrm{MHydrochloric}$ acid $(5 \mathrm{ml})$ was added to the ash and brought to boiling. This was filtered and $10 \mathrm{ml}$ of filtrate solution was pipetted into $50 \mathrm{ml}$ volumetric flask and $10 \mathrm{ml}$ of Vanadate-molybdate yellow added and the flask was made up to mark with distilled water, stopped and left for 10minutes for full yellow development. The spectrometric absorbance was taken.

\section{Water absorption capacity}

The water absorption capacity (WAC) were determined by the method of Sosulski et al. (1986). $1 \mathrm{~g}$ sample was 
Arisa et al. 069

Table 1. Recipe for biscuit

\begin{tabular}{lc}
\hline Ingredients & Weight (g) \\
\hline Flour & 200 \\
Sugar & 50 \\
Fat & 100 \\
Baking powder & 2.0 \\
Salt & 0.20 \\
Egg & One whole egg \\
Vanilla flavour & 0.20 \\
Milk & 3 tablespoonful \\
\hline
\end{tabular}

Source: Nwabueze \& Atuonwu, (2007)

mixed with $10 \mathrm{ml}$ of distilled water, kept at ambient temperature for $30 \mathrm{~min}$ and centrifuged for $10 \mathrm{~min}$ at $2000 \times$ g. WAC was expressed as percent water or oil bound per gram of the sample.

\section{Bulk density}

The bulk density (BD) was determined according to the method described by lgbagul et al. (2013). $5 \mathrm{~g}$ of sample and $50 \mathrm{ml}$ of deionised water were introduced into a 100 $\mathrm{ml}$ graduated cylinder.The bottom of the cylinder was tapped until there was no observable decrease in the volume of the sample. The BD was expressed as follows;

Bulk Density $=$ Weight of sample $(\mathrm{g})$ Volume of sample (ml)

\section{Swelling capacity}

The method of Okaka and Potter (1977) with some modifications was used for determining the swelling capacity (SC). The $1 \mathrm{~g}$ of sample was added to 10 deionized water in a $100 \mathrm{ml}$ graduated cylinder with water added to adjust the total volume to $50 \mathrm{ml}$. The top of the graduated cylinder was tightly covered and mixed by inverting the cylinder. The suspension was inverted again after $2 \mathrm{~min}$ and allowed to stand for further $30 \mathrm{~min}$. The volume (in $\mathrm{ml}$ ) occupied by the sample was taken after 30 $\min$.

\section{Foamstability}

The foam stability (FS) was determined according the method described by Chandra et al. (2015). $1 \mathrm{~g}$ flour sample was added to $50 \mathrm{ml}$ distilled waterat $30 \pm 2^{\circ} \mathrm{C}$ in a graduated cylinder. The suspension was mixed and shaken for $5 \mathrm{~min}$ to foam. The foam volume was recorded1 hour after whipping. The foam stability was determined as a percentageof initial foam volume.

\section{Sensory evaluation}

The organoleptic evaluation of the biscuits samples was carried out for consumer acceptance and preference using 25 trained panelists. They were to evaluate the sensory properties based on; colour, aroma, taste, texture and overall acceptability using a 9 (nine) point hedonic scale where 1 represents "extremely dislike" and 9 "extremely like" respectively.

\section{Statistical Analysis}

All data derived from experimental work were statistically analysed using the Statistical Package for the Social Sciences v. 20.0 (SPSS, Chicago, IL, USA). The means were compared with aid of a one-way ANOVA and a significance level of $p<0.05$ was set. The Duncan's multiple comparison post hoc test was used in interpreting the differences among the mean values.

\section{RESULTS AND DISCUSSION}

\section{Proximate composition of composite flours}

The proximate composition of the composite flours is presented in Table 2. The ash content of the flour samples ranged between 2.35 to $3.24 \%$ compared to WWF $(1.15 \%)$. This showed that incorporation of beniseed may enhance the amount of mineral intake in the food product and as such would contribute appreciable dietary amounts of mineral (Osidipe, 2012; Afolabi et al. 2001). The moisture content of the substituted flour samples ranged from 12.15 to $9.86 \%$ with WBT3 having the highest value. The moisture content is an index of the shelf stability of a product. The fat content the composite flours ranged from $0.78 \%$ to $6.25 \%$ when compared to wheat flour $(0.35 \%)$. The progressive increase in the fat contents of the products may be attributable to addition of full-fat beniseed flour, which is an oil seed. Ayo et al. (2010) reported a nonsignificant difference in the fat content of defatted beniseed and Acha flour. However, Oloyo (1999) reported a significant increase in fat content of "Kokoro" enriched with beniseed.

The protein content of the substituted flours increased significantly $(p<0.05)$ WBT1 $(9.26 \%)$, WBT2 $(9.87 \%)$ and WBT3 $(10.0 \%)$ when compared to WF $(9.12 \%)$. This increase is due to the high protein content of beniseed and trifoliate yam flours. Similar findings were reported by earlier workers (Afolabi 2001; Ayoet al. 2010). Alobo (2006) reported that the beniseed has a good balance of amino acids with a chemical score of $62 \%$ and a net protein utilization of $54 \%$. 
070 Afr. J. Food Sci. Technol.

Table 2. Proximate composition of flour samples

\begin{tabular}{ccccccc}
\hline Samples & $\begin{array}{c}\text { Ash } \\
(\%)\end{array}$ & $\begin{array}{c}\text { Moisture } \\
(\%)\end{array}$ & $\begin{array}{c}\text { Fat } \\
(\%)\end{array}$ & $\begin{array}{c}\text { Protein } \\
(\%)\end{array}$ & $\begin{array}{c}\text { Crude fibre } \\
(\%)\end{array}$ & $\begin{array}{c}\text { Carbohydrate } \\
(\%)\end{array}$ \\
\hline WWF & $1.15^{\mathrm{a}}$ & $13.14^{\mathrm{d}}$ & $0.35^{\mathrm{a}}$ & $9.12^{\mathrm{a}}$ & $0.25^{\mathrm{a}}$ & $76.02^{\mathrm{d}}$ \\
WBT1 & $2.35^{\mathrm{b}}$ & $12.15^{\mathrm{c}}$ & $0.78^{\mathrm{b}}$ & $9.26^{\mathrm{b}}$ & $0.49^{\mathrm{b}}$ & $74.99^{\mathrm{c}}$ \\
WBT2 & $2.95^{\mathrm{c}}$ & $11.88^{\mathrm{b}}$ & $1.49^{\mathrm{c}}$ & $9.87^{\mathrm{c}}$ & $0.98^{\mathrm{c}}$ & $72.85^{\mathrm{b}}$ \\
WBT3 & $3.24^{\mathrm{d}}$ & $9.86^{\mathrm{a}}$ & $6.25^{\mathrm{a}}$ & $10.00^{\mathrm{d}}$ & $2.76^{\mathrm{d}}$ & $67.91^{\mathrm{a}}$ \\
\hline
\end{tabular}

*Values within the same column with different superscript letters are significantly different $(p<0.05)$ from each other WWF; Whole Wheat flour, WBT1, 90\% Wheat flour $+5 \%$ Beniseed flour + 5\% Trifoliate yam flour, WBT2; $70 \%$ Wheat flour $+15 \%$ Beniseed flour+ $15 \%$ Trifoliate yam flour, WBT3; $50 \%$ Wheat flour $+25 \%$ Beniseed flour $+25 \%$ Trifoliate yam flour

Table 3 .Functional properties of flour samples

\begin{tabular}{lcccc}
\hline Samples & Bulk density & Swelling capacity & Water absorption capacity & Foam stability \\
\hline & $(\mathrm{g} / \mathrm{ml})$ & $(\mathrm{ml})$ & $(\%)$ & $(\%)$ \\
WWF & $0.74^{\mathrm{c}}$ & $8.36^{\mathrm{b}}$ & $60.75^{\mathrm{a}}$ & $52.24^{\mathrm{a}}$ \\
WBT1 & $0.66^{\mathrm{b}}$ & $6.85^{\mathrm{c}}$ & $149.92^{\mathrm{d}}$ & $56.36^{\mathrm{b}}$ \\
WBT2 & $0.58^{\mathrm{a}}$ & $5.75^{\mathrm{a}}$ & $133.03^{\mathrm{c}}$ & $71.24^{\mathrm{c}}$ \\
WBT3 & $0.57^{\mathrm{a}}$ & $6.40^{\mathrm{b}}$ & $128.42^{\mathrm{b}}$ & $76.33^{\mathrm{d}}$ \\
\hline
\end{tabular}

*Values within the same column with different superscript letters are significantly different $(p<0.05)$ from each other. WWF; Whole Wheat flour, WBT1, 90\% Wheat flour $+5 \%$ Beniseed flour + 5\% Trifoliate yam flour, WBT2; 70\% Wheat flour+15\% Beniseed flour+ 15\% Trifoliate yam flour, WBT3; 50\% Wheat flour+25\% Beniseed flour+ 25\% Trifoliate yam flour

There was a significant difference between the crude fiber content of the wheat flour and the composite flours $(p<0.05)$. Fiber is regarded as essential, as it absorbs water and provides roughage for the bowels, assisting intestinal transit. Abiodun et al. (2010) reported an increase in fiber content when yam flour was fortified with soybean however Ayindeet al. (2012) reported a decrease in fibre content of "Kokoro'fortified with beniseed. The carbohydrate content decreased as the substitution levels increased. This was in agreement with the findings of Jimoh and Olatidoye (2009) and Emmanuel-lkpeme et al. (2012), who reported a decrease in carbohydrate content with increase in soybean flour fortification.

\section{Functional properties of flour samples}

The functional properties of the flour blends are presented in table 3 .The bulk density (BD) of the composite flour was in this order; WBT1> WBT2> WBT3 $(0.66 \mathrm{~g} / \mathrm{ml}>0.58 \mathrm{~g} / \mathrm{ml}>0.57 \mathrm{~g} / \mathrm{ml}$ respectively). However, WWF had a higher BD than the composite flours $(0.74 \mathrm{~g} / \mathrm{ml})$. This indicates that a lesser package requirement is required with increase in beniseed and trifoliate yam flour substitution in comparison to WWF. Swelling capacity (SC) is the ability of the starch inherent in flour to hold water through hydrogen bonding. The swelling capacity of flours depends on; size of particles, types of variety and types of processing methods
(Samsher, 2013). There was a significant difference $(p<0.05)$ in the SC of the flour blends; WBT1 > WBT3 > WBT2; $(6.85 \mathrm{ml}, 6.40 \mathrm{ml}$ and $5.75 \mathrm{ml}$ respectively). However, WWF had a better SC (8.36\%) when compared to the composite flours. Water absorption capacity (WAC) of a flour is the ability of its particles to entrap large amounts of water such that exudation is prevented (Hsu et al. 2003). It varies with size, shape, the presence of proteins and carbohydrates. WWF had anattenuated WAC $(60.75 \%)$ in comparison with the composite flours. A similar trend as seen the BD results was observed. Increase in substitution markedly decreased the WAC of the flour samples (149.92\% to $128.42 \%)$ which implies that the WBT1 sample was the most hydrophilic and WBT3 being hydrophobic. The foam stability of the composite flour samples increased sharply with increasing beniseed and trifoliate yam substitution; WBT1 < WBT2 < WBT3 (56.36\%, 71.24\% and 76.33\% respectively). The highest foam capacity was observed for the WBT3 sample which could be attributed to a higher protein content. Protein in the dispersion may cause a lowering of the surface tension at the water-air interface (forms a continuous cohesive film around the air bubbles) (Kaushal et al. 2012).

\section{Some mineral composition of composite flours}

The mineral composition of the composite flours are shown in table 4. Substitution increase of beniseed and 
Table 4 . Some micronutrient composition of flour samples

\begin{tabular}{lcccccc}
\hline Samples & $\begin{array}{c}\text { Magnesium } \\
(\%)\end{array}$ & $\begin{array}{c}\text { Manganese } \\
(\%)\end{array}$ & $\begin{array}{c}\text { Sodium } \\
(\%)\end{array}$ & $\begin{array}{c}\text { Calcium } \\
(\%)\end{array}$ & $\begin{array}{c}\text { Iron } \\
(\%)\end{array}$ & $\begin{array}{c}\text { Copper } \\
(\%)\end{array}$ \\
\hline WWF & $0.16^{\mathrm{a}}$ & $0.02^{\mathrm{a}}$ & $0.60^{\mathrm{a}}$ & $0.39^{\mathrm{a}}$ & $0.62^{\mathrm{b}}$ & $0.31^{\mathrm{a}}$ \\
WBT1 & $0.38^{\mathrm{b}}$ & $0.01^{\mathrm{a}}$ & $0.93^{\mathrm{b}}$ & $0.51^{\mathrm{b}}$ & $0.53^{\mathrm{a}}$ & $0.58^{\mathrm{b}}$ \\
WBT2 & $0.46^{\mathrm{c}}$ & $0.05^{\mathrm{b}}$ & $1.04^{\mathrm{c}}$ & $0.70^{\mathrm{c}}$ & $0.56^{\mathrm{a}}$ & $0.66^{\mathrm{c}}$ \\
WBT3 & $0.65^{\mathrm{a}}$ & $0.08^{\mathrm{c}}$ & $1.07^{\mathrm{c}}$ & $0.89^{\mathrm{d}}$ & $0.62^{\mathrm{b}}$ & $0.73^{\mathrm{d}}$ \\
\hline
\end{tabular}

*Values within the same column with different superscript letters are significantly different $(p<0.05)$ from each other WWF; Whole Wheat flour, WBT1, 90\% Wheat flour+5\% Beniseed flour+ 5\% Trifoliate yam flour, WBT2; 70\% Wheat flour+15\% Beniseed flour+ $15 \%$ Trifoliate yam flour, WBT3; $50 \%$ Wheat flour $+25 \%$ Beniseed flour $+25 \%$ Trifoliate yam flour

Table 5. Proximate composition of biscuit samples

\begin{tabular}{lcccccc}
\hline Samples & $\begin{array}{c}\text { Ash } \\
(\%)\end{array}$ & $\begin{array}{c}\text { Moisture } \\
(\%)\end{array}$ & $\begin{array}{c}\text { Fat } \\
(\%)\end{array}$ & $\begin{array}{c}\text { Protein } \\
(\%)\end{array}$ & $\begin{array}{c}\text { Crude fibre } \\
(\%)\end{array}$ & $\begin{array}{c}\text { Carbohydrat } \\
(\%)\end{array}$ \\
\hline WWFB & $2.29^{\mathrm{a}}$ & $7.25^{\mathrm{d}}$ & $10.89^{\mathrm{a}}$ & $9.83^{\mathrm{a}}$ & $0.37^{\mathrm{a}}$ & $69.39^{\mathrm{d}}$ \\
WBTB1 & $2.65^{\mathrm{b}}$ & $6.17^{\mathrm{c}}$ & $12.13^{\mathrm{b}}$ & $10.10^{\mathrm{b}}$ & $0.68^{\mathrm{b}}$ & $68.08^{\mathrm{c}}$ \\
WBTB2 & $2.72^{\mathrm{c}}$ & $5.03^{\mathrm{b}}$ & $13.83^{\mathrm{c}}$ & $11.32^{\mathrm{c}}$ & $1.01^{\mathrm{c}}$ & $66.10^{\mathrm{b}}$ \\
WBTB3 & $3.45^{\mathrm{a}}$ & $4.50^{\mathrm{a}}$ & $14.92^{\mathrm{d}}$ & $13.59^{\mathrm{d}}$ & $1.98^{\mathrm{d}}$ & $61.84^{\mathrm{a}}$ \\
\hline
\end{tabular}

*Values within the same column with different superscript letters are significantly different $(p<0.05)$ from each other. WWFB; Whole Wheat flour biscuit; WBTB1: $90 \%$ Wheat flour+5\% Beniseed flour+ $5 \%$ Trifoliate yam flour biscuit, WBTB2; $70 \%$ Wheat flour $+15 \%$ Beniseed flour $+15 \%$ Trifoliate yam flour biscuit, WBTB3; 50\% Wheat flour $+25 \%$ Beniseed flour $+25 \%$ Trifoliate yam flour biscuit

trifoliate yam flours resulted in a progressive increase in the mineral content of the composite flours. Iron forms a constituent of hemoglobin which takes part in the transportation of oxygen from the lungs to the tissue. There was no significant difference $(p>0.05)$ seen between WBT3 and WWF with respect to iron content. The magnesium content of the composite flours ranged from 0.38 to $0.65 \%$ and were significantly higher $(p<0.05)$ than WWF $(0.16 \%)$. Magnesium plays an important role in normal calcium and phosphorus metabolism in man. Furthermore, a similar trend of WBT1<WBT2 <WBT3 in terms of the manganese content was also seen. Although no significant effect $(p>0.05)$ was observed between WWF and WBT1 samples.

Manganese functions in many enzymes and it activates certain enzymes which take part in the digestion and metabolism of carbohydrates, proteins and lipids. Sodium is essential for normal functioning of the body and it also plays a role in the regulation of acid-base balance and water metabolism in the body. In addition, there was a similar increase in both the calcium and copper contents $(0.38 \%$ and $0.15 \%$, respectively). Calcium is a micronutrient essential to health and wellbeing. It performs diverse biological function in the human body. It serves as; a second messenger for nearly every biological process, stabilizes protein and calcium as well as necessary for normal ossification of bones and normal nerve impulse transmission (Weaver and Heaney, 2006; Raheena 2007). Also, copper stimulates the absorption of iron and it is a constituent of the elastic connective tissue protein elastin. Potassium is an important constituent of cells and it helps with muscular function.

\section{Proximate composition of the composite flour biscuits}

The proximate composition of the composite flour biscuits are presented in table 5 . The proximate composition of the composite flour biscuit samples showed a similar trend with their parents. There was a significant elevation $(p<0.05)$ of the ash content of biscuit samples as substitution levels of beniseed and Trifoliate yam increased (2.65 to $3.45 \%)$. The ash contents of all the composite flour biscuit samples were significantly higher than WWB (2.29\%). Likewise, the fat content of the biscuit samples was also boosted significantly $(p<0.05)$ $(12.13$ to $14.92 \%)$ and were all higher than WWB $(10.89 \%)$. This increase in the fat content may be due to the appreciable amount of fat in the beniseed seeds. Similarly, the protein composition of the composite flour biscuits significantly progressed $(p<0.05)$ as substation levels increased (10.10-13.59\%). The composite flour biscuit samples had a better protein quality than WWB (9.83). This increase is apparently attributed to the protein in sesame seeds (El-Adawy, 1997). Furthermore, a significant increase $(p<0.05)$ was also seen in the crude fiber content of the biscuit samples (0.68-1.98\%) which was higher than WWB (0.37). High fibre is beneficial to the body, as it could help to maintain bowel integrity, lower blood cholesterol level, and control blood sugar level, hence consumption of these products would provide appreciable amount of fiber to the body for proper functioning of the digestive and excretory systems Conversely, biscuits made from with higher of beniseed and Trifoliate yam had a reducing effect on both moisture content and carbohydrate contents and were significantly 
072 Afr. J. Food Sci. Technol.

Table 6. Sensorycharacteristics of the beniseed, trifoliate yam and wheat flour biscuit

\begin{tabular}{llllccrr}
\hline Samples & Colour & Texture & Aroma & Taste & Flavor & Crispness & Overall Acceptability \\
\hline WWFB & $6.67^{\mathrm{b}}$ & $6.07^{\mathrm{b}}$ & $5.80^{\mathrm{a}}$ & $5.13^{\mathrm{b}}$ & $5.47^{\mathrm{b}}$ & $6.40^{\mathrm{b}}$ & $5.87^{\mathrm{a}}$ \\
WBTB1 & $8.07^{\mathrm{a}}$ & $7.80^{\mathrm{a}}$ & $8.13^{\mathrm{b}}$ & $8.27^{\mathrm{d}}$ & $7.93^{\mathrm{d}}$ & $8.00^{\mathrm{c}}$ & $8.33^{\mathrm{c}}$ \\
WBTB2 & $6.00^{\mathrm{b}}$ & $6.67^{\mathrm{a}}$ & $8.00^{\mathrm{b}}$ & $6.93^{\mathrm{c}}$ & $6.73^{\mathrm{c}}$ & $6.80^{\mathrm{b}}$ & $7.40^{\mathrm{b}}$ \\
WBTB3 & $5.73^{\mathrm{c}}$ & $5.73^{\mathrm{c}}$ & $6.07^{\mathrm{a}}$ & $4.13^{\mathrm{a}}$ & $4.53^{\mathrm{a}}$ & $5.53^{\mathrm{a}}$ & $5.93^{\mathrm{a}}$ \\
\hline
\end{tabular}

*Values within the same column with different superscript letters are significantly different $(p<0.05)$ from each other. WWFB; Whole Wheat flour biscuit; WBTB1: 90\% Wheat flour+5\% Beniseed flour+ 5\% Trifoliate yam flour biscuit, WBTB2; 70\% Wheat flour $+15 \%$ Beniseed flour+ 15\% Trifoliate yam flour biscuit, WBTB3; $50 \%$ Wheat flour $+25 \%$ Beniseed flour $+25 \%$ Trifoliate yam flour biscuit

lesser $(P<0.05)$ than WWB $(7.25 \%$ and $69.39 \%$ respectively). The moisture content of biscuit samples significantly decreased $(6.17 \%-4.50 \%)$. Christine et al.(2012) reported a similar trend in bread and cake samples produced from beniseed and wheat composite flour. Similarly, the carbohydrate contents slumped significantly $(68.08-61.84 \%) \quad(p<0.05)$.

\section{Sensory characteristics of composite flour biscuits}

The result for sensory evaluation is presented in table 6 . The biscuit samples were evaluated for colour, texture, aroma, taste, flavor, crispness and overall acceptability. In terms colour, there was a significant difference $(p<0.05)$ observed by the panelists but WBTB1 was most preferred (8.07). However, there was no significant difference $(p<0.05)$ seen between WBTB2 and WWFB (6.00 and 6.67 respectively) but WWFB was most preferred. A significant difference $(p<.05)$ in texture was detected by the panelist with WBTB1 having the highest preference (7.80). Though no significant difference $(p<0.05)$ was perceived between WBTB1 and WBTB2 (7.80 and 6.67 respectively) but WBTB1 was most preferred. Aroma was perceived to be significantly different $(p<0.05)$ among the samples with WBTB1 having the highest score of 8.13. In addition, WWFB and WBTB3 as well as WBTB1 and WBTB2 were not significantly different $(p<0.05)$ from each other $(5.80$ and 6.07 respectively) and (8.13 and 8.00 respectively). Taking a look at taste and flavor, it was discovered that there was a significant difference in all the samples $(p<0.05)$ with WBTB1 being the most desired $(8.27$ and 7.93 respectively). Also, there was a significant difference in crispiness of the biscuits $(p<0.05)$ with WBTB1 being the most desirable $(8.00 \%)$. However, there was no significant difference seen between WFB and WBTB2 (6.40 and 6.80). Furthermore, the most accepted biscuit sample was that of WBTB1 (8.33). WWFB was the least accepted (5.87),moreover, it was not significant different $(p>0.05)$ from WBTB3.

\section{CONCLUSION}

The research reveals that the inclusion of beniseed and trifoliate yam flour improved the proximate composition, and mineral quality of flour samples as well as the biscuits produced. Although, it had a poor effect on the carbohydrate and moisture contents. In addition, blending beniseed with trifoliate yam flour up to $15 \%$ level produced samples which can be used for the production of bakery products with improved functional properties and production time. Also, the inclusion of beniseed and trifoliate yam flours improved some sensory parameters which could be further investigated. The biscuits produced with $5 \%$ beniseed and trifoliate yam flours (WBTB1) had the highest overall acceptability. This establishes the fact that the inclusion of $5 \%$ beniseed and trifoliate yam flours will compete favorably with whole wheat flour in terms of biscuit production. Therefore, this study has provided further insight the suitability of cerealtuber based flours as a suitable adjunct to whole wheat flour utilisability in the baking industry. Also, most especially, in the utilization of trifoliate yam which has proven to be difficult to process.

\section{REFERENCES}

AOAC (1990). Official methods of Analysis of the Association of Official Analytical Chemists, $15^{\text {th }}$ edn. AOAC, USA.

Abou-Garbia HA, Shehata AAY, Shahidi F (2000). Effect of Processing on oxidative stability and lipid classes of Sesame oil. Food Res Intl 33: $331-340$.

Afolabi WAO, Oguntona CRB, Fakunmoju BB (2001). Acceptability and chemical composition of breadfrom beniseed composite flour. J Nutr Food Sci 31(6): 310-313.

Akanji AM, Ologhobo AD, Emiola IA, Oladunjoye IO (2003). Effect of raw and differently processed sesame seeds and performance and nutrition utilization of broiler chickens. Proceedings of the 28th AnnualConference of the Nigerian Society of Animal Production23: 184-186.

AOAC. (2004). Official methods of Analysis, 15th edn. Association of official Analytical Chemistry, USA, pp 806-842.

Alobo AP (2006). Effect of sesame seed on millet biscuit. J Plant Foods Hum Nutr 64: 21-27.

Abiodun, OA, Adegbite JA, Oladipo TS (2010). Effect of cassava starch substitution on the functional and sensory properties of trifoliate yam (Dioscorea dumetorum) flours. AfrJ Food AgricNutr Dev 10(7).

Ayo JA, Ikuomola DS, Esan YO, Onuoha OG, Ayo VA, Ekele V (2010). Effect of added defatted beniseed on the quality of Acha based biscuits. Cont J Food Sci Technol 4: 7-13.

Ayinde FA, Bolaji OT, Abdulsalaam RB, Osidipe O (2012). Functional properties and quality evaluation of kokoro blended with beniseed cake (Sesame indicum). Afr J Food Sci 6(5):117-123.

Adeniyan OO, Ibukun EO1, Ogunbolude Y, Eseigbe MI. (2013).Effect of Boiling on the Nutritional composition and antioxidant properties of Beniseed (Sesamum indicum L.)Food Sci Qual Manag.11:40 - 48. 
Abiodun OA, Akinoso R J (2015). Textural and sensory properties of trifoliate yam (Dioscorea dumetorum) flour and stiff dough 'amala'. J Food Sci Technol 52: 2894.

Ceirwyn SJ (1998). Analytical Chemistry of Food. Chapman and Hall,London,pp 75-77.Christine El, Christopher E, Godwin I (2012). Nutritional and organoleptic properties of wheat

(Triticum aestivum) and beniseed (Sesame indicum) composite flour baked foods. J Food Res 1(3): 84-91.

Chandra S, Singh S, Kumari DJ, (2015). Evaluation of functional properties of composite flours and sensorialattributes of composite flour biscuits. Food Sci Technol 52: 3681.

Dawodu, FA (2009). Physico-chemical studies on oil extraction processes from some Nigerian grown plant seeds. Electronic Journal of Environmental, Agricultural and Food Chemistry, 8(2): 102-110.

El-Adawy TA (1997). Effect of sesame seed protein supplementation on the nutrition, physical, chemical and sensory properties of wheat flour bread, Food Chem59:7-14.

Ezeocha VC, Omodamiro RM, Oti E, Chukwu GO (2011). Development of trifoliate yam: Cocoyamcomposite flour for fufu production. $J$ Stored Prod Posthar Res 2(9): 184-188.

Eke-Ejiofor J, Owuno F (2012). Functional and Pasting Properties of Wheat/Three-leaved Yam (Dioscorea dumentorum) composite flour blend. Global Res J Agric Bio Sci 3(4): 330-335.

Emmanuel-Ikpeme C, Eneji C, Igile G (2012). Nutritional and organoleptic properties of wheat (Triticumaestivum) and beniseed (Sesame indicum) composite flour baked foods. J Food Res 1(3): 84.

FAO (2003). Yams: Post-Harvest Operation. Food and Agricultural Organisation, New Zealand.

Hsu CL, Chen W, Weng YM, Tseng CY (2003). Chemical composition, physicalproperties, and antioxidant activities of yam flours as affected by different drying methods. Food Chem, 83(1): 85-92.

Himeda M, Yanou, N., Fombang, E,Facho B, Kitissou P, Mbofung CMF, Scher J(2014). Chemical

composition, functional andsensorycharacteristics of wheat-taro composite flours and biscuits. J Food Sci Technol 51: 1893.

Igbabul, B, Adole, D, Sule, S. (2013). Proximate composition, functional and sensory properties of bambara nut (Voandzeia subterranean), cassava (Manihot esculentus) and soybean

(Glycine max) flour blends for "Akpekpa" production. Current Research in Nutrition and Food Sci J., 1(2): 147-155.

Jimoh KO, Olatidoye OP (2009). Evaluation of physicochemical and rheological characteristics of soybean fortified yam flour. J Appl Biosci 13: 703-706.

Kaushal P, Kumar V, Sharma HK (2012). Comparative study of physicochemical, functional, anti-nutritional and pasting properties of taro (Colocasia esculenta), rice (Oryza sativa), pigeon pea (Cajanus cajan) flour and their blends. LWT-Food Sci Technol 48: 59-68.

Martin FE, Degras L (1978). Tropicalyams and their potentials. part 6 . minor cultivated Dioscorea Specie. Agricultural Handbook No. 538 , USDA, pp. 23.

Mohammed MI, Hamza ZU (2008). Physicochemical properties of oil extracts from Sesamum indicum L. seeds grown in Jigawa state, Nigeria. J Appl Sci Environ Man 12(2): 99-101.

Morris JB (2002). Food, industrial, nutraceutical, and pharmaceutical uses of sesame genetic resources. Trends in new crops and new uses,pp 153-156.
Narayana K, Narasinga RMS (1982). Functional properties of raw and heat processedwinged bean(Psophocarpus tetragonolobus) flour. JFood Sci,47(5): 1534-1538. In: Janick J, Whipkey A (eds)New Crops and New Uses, ASHS,Alexander,pp $153-156$

Njoku OU, Boniface JE, Obitte NC, Odimegwu DC, Ogbu HI (2009). Some nutriceutical potential of beniseed oil. Intl J Applied Res Nat Prod 2(4): 11-19.

Ogbuagu MN (2008). Nutritive and Anti-Nutritive Composition of the Wild (In-Edible) Species of Dioscoreabulbifera (Potato Yam) and Dioscorea dumentorum(Bitter Yam). J Food Technol, 6(5): 224-226.

Okaka JC, Potter NN (1977). Functional and storage properties of cowpea-wheat flour blends in bread making. J Food Sci 42:828-833.

Oloyo RA (1999). Some aspect of nutritive quality of some maize based traditional convenience foods Niger. Food J 22:61.

Osidipe $\mathrm{O}$ (2012). Functional properties and quality evaluation of kokoro blended with beniseed cake Sesame Indicum. Afr J Food Sci 6(5):117-123.

Raheena B (2007). A text book of foods, nutrition \& dietetics. Sterling Publication Pvt. Ltd.

Samsher CS (2013). Assessment of functional properties of different flours. African J. Agricultural Research 8(38):4849-4852.

Sefa-Dedeh SK, Afoakwa EO (2001). Biochemical and textural changes in trifoliate yam (Dioscoreadumetorum) tubers after harvest. IFT Annual meeting-New Orleans, Louisiana.

Sosulski FW, Garratt MO, Slinkard AE (1976). Functional properties of ten legume flours. IntlJ Food SciTechnol 9:66-69.

Uaboi-Egbenni PO, Sobande AO, Okolie PN, Teniola O, Ofodiogo C (2008). Proximate composition of whole, dehulled and fermented beniseed (sesame indicum) with associated bacterial species. Nig Food J, 26(1).

USDA (2009). United States Department of Agriculture National Nutrient Database for Standard Reference, Release22.

Weiss EA (2000). Oil Seed Crop. 2nd edn. Blackwell Longman, USA,pp 131-164.

Weaver CM, Heaney RP (2006). Food sources, supplements, and bioavailability. In calcium in human health, Humana Press,pp 129 142. 